\title{
SYSTEMATIC LITERATURE REVIEW OF SCIENTIFIC JOURNAL: TRANSLATIONSTECHNIQUE OF LITERARY TEXT OF POETRY
}

\author{
Samuel Jusuf Litualy ${ }^{1}$, Eldaa Crystle Wenno ${ }^{2}$, Henderika Serpara ${ }^{3}$ \\ Pattimura University, German Language Education Study Program ${ }^{123}$ \\ Email: samly_56e@yahoo.co.id
}

\begin{abstract}
Poetry is a unique literary work and is not easily translated from source language to target language because in the process, wherever possible maintain the inner atmosphere of the work (mood, tone). At the same time, translators should look for equivalents to the formal form of the poem itself appropriately, such as the number of lines (especially for sonnet type), rhyme (praying) and syllable (number of syllables). Therefore, it is necessary to review the journal paper that discusses the technique of translating the literary text of poetry. The method used by this study is Systematic Literature Review (SLR) on journal paper published from 20132021. There is one Research Question (RQ) set out in this study. The final result obtained from this study is that there are twenty-one techniques for translating poetry literary texts that can be used by translators according to the times, needs and objectives of translators.
\end{abstract}

Keywords : poetry, techniques of translation, systematic literature review

\section{Introduction}

Translation is the transfer of meaning from the source language into the target language (Hatim \& Munday, 2013). This diversion is done through a semantis structure. Meanings are diverted and must be maintained, while forms may be changed (Kudriyah, 2020). This means that a translator must be able to interpret lexical, grammatical, contextual, textual and cultural meanings from the source language to the target language. One of them is the translation of literary works which is an important branch of discipline in the study of translation because this discipline becomes one of the means of understanding between nations so that understanding meaning is needed. (Prihantono, 2014). Translating literary works is a challenging and complex task. This is because the literary genre emphasizes the beauty of language that contains many elements of meaning. (Salleh \& Ahmad, 2015).

Poetry is one type of literary work that has its own uniqueness. Not only in terms of form, but also the sounds of the language used, the expressions produced, and the emotions it emits. In translating poetry a translator must be able to convey the content and meaning in the source language. According to Nurhidayah (2018). Translating poetry is among the hardest translations because in the process, wherever possible maintained the inner atmosphere (mood, tone) of the work. At the same time, the translator must look for the equivalent of the formal form of the poem itself precisely, for example the number of lines (especially for the sonnet type), rhyme and 
syllable (number of syllables). To keep it reasonable, the transfer of content and message of the poetry must still be brought. Thus all these qualifications are largely determined by the sensibilities of a literarytranslator.

Literary works, whether in the form of poetry, prose, or actions are not easy to translate. There are several obstacles that are obstacles, that is: a cultural gap between readers in the source language and the target language (Newmark, 1988). To be a good translator of poetry literature, a translator must master the source language and the target language, understand the theory of translation, and most importantly understand deeply about literature, and have a strong literary sensibility, because literary works contain aesthetic values, namely having emotional elements, the effect of the beauty of words and expressions, and the effect of the beauty of sound. Kartika (2017) in the results of her research found that translation techniques that are often used in translating poetry are techniques of adaptation, elision, amplification and compensation. Zemova \& Bozhko (2019) adds that there are two approaches to poetry translation: free translation and adaptation. The purpose of the free approach is to convey the mood and beauty of the poem, regardless of its original form..

Based on the above exposure, it can be concluded that poetry is one type of literary work that has its own uniqueness, both in terms of form, and the sounds of the language used, the expressions produced, and the emotions it emits. Thus it is not easy for a person to translate the literary text of poetry, there needs to be certain techniques in its translating. This research aims to find and produce several studies on the translation of poetry literary texts through systematic literature review of scientific journals.

\section{Research Methods}

This research method uses systematic literature review (SLR). In general, SLR is a method that identifies, assesses, and interprets findings on a research topic to answer a previously established research question. (Kitchenham et al., 2009).

The methods in this study have several process flows, namely:

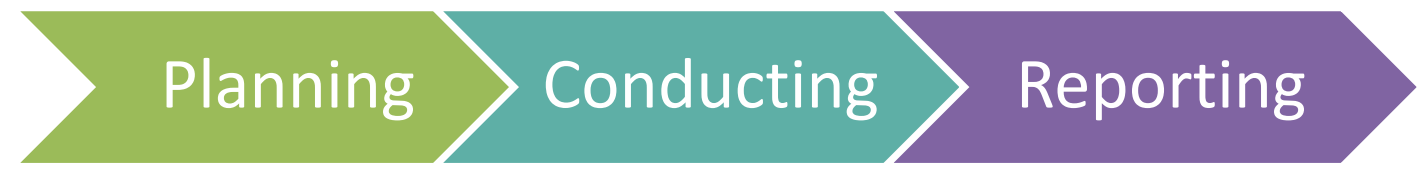

Figure 1. Research Stage

Figure 1. Is a research stage consisting of the planning stage is the initial stage of doing SLR, then entering the conducting stage that is the implementation stage of SLR, and the last stage is Reporting which is the stage of writing SLR into a report. Research Object

The object of this research is the translation of the literary text of Poetry. The translation of the literary text of poetry as an object of research because poetry is a form of literary work that expresses thoughts and feelings through beautiful words by concentrating on physical structures and inner structures. Thus, when a poem is 
translated, the translator must use certain techniques or strategies so that the delivery of the meaning, authenticity and beauty of the poem can be conveyed even though it is translated into various languages.

Research Question.

Research Question are made based on the needs of the selected topic. The following is a research question in this study, namely: what are the techniques used in translating the literary text of poetry?

Search Process.

Search Process atau The search process is used to obtain relevant sources to answer Research Questions (RQ) and other related references. The search process is done using a search engine (Google Chrome) with the following site address: https://www.scopus.com/home.uri,https://www.sciencedirect.com/, and https://scholar.google.co.id/.

\section{Inclusion and Exclusion Criteria.}

This stage is done to decide whether the data found is worth using in SLR research or not. This study is worth choosing if there are the following criteria: The data used is in the period 2013-2021.

1. Data obtained through the site https://www.scopus.com/home.uri, https://www.sciencedirect.com/, and https://scholar.google.co.id/.

2. The data used is only journal papers related to the translation of poetry literary texts.

Quality Assesment.

In the SLR study, the data found, evaluated based on the following quality assessment criteria questions:

1. QA1. What journal papers were published in 2013-2021?

2. QA2. Does journal paper discuss the techniques used to translate poetry literary texts??

3. QA3. Does the journal paper discuss the methods of data collection used to translate the literary text of poetry??

Each paper will be assigned a value based on the question above..

1. Yes : for journal papers that are in accordance with the questions in quality assessment.

2. No: for journal papers that do not match the questions in the quality assessment.

Data Collection.

At this stage, the data needed in the research, collected for the next analysis process. Here are the data collection steps.:

1. Visit the site

https://www.scopus.com/home.uri,https://www.sciencedirect.com/, dan https://scholar.google.co.id/.

2. Input Keywords "Poetry Translation or Poem Translation". 
3. In "Special range", enter 2013 in the first box and 2021 on the second box. This indicates that the range of journal papers selected is from 2013-2021..

Data Analysis

Data that has been collected at a previous stage will be analyzed at this stage. The results that have been analyzed will answer the previously determined research question..

\section{Documentation}

In this phase, the stage until the results of the study are written in paper form in accordance with the format that has been provided..

\section{Results and Discussions}

The Resukt of the search process and inclusion and exclusion criteria is only taken 10 journal papers that have been in accordance with the criteria, namely journal papers published in the period 2013-2021 and have discussions related to "translation of poetry literary texts". The information obtained is then grouped into several types of journals. The following are the types of journals that have been successfully obtained.:

Table 1. Grouping by Journal Type

\begin{tabular}{|c|c|c|c|}
\hline $\mathbf{N r}$ & Name of Jurnal & Year of Publication & Sum \\
\hline 1 & $\begin{array}{l}\text { Procedia - Social and Behavioral } \\
\text { Sciences, }\end{array}$ & (Kharmandar \& Karimnia, 2013) & \multirow[t]{2}{*}{2} \\
\hline 2 & $\begin{array}{l}\text { Procedia - Social and Behavioral } \\
\text { Sciences, }\end{array}$ & (Prokopieva \& Leushina, 2014) & \\
\hline 3 & Journal of Literature and Art Studies & (Ndong, 2017) & 1 \\
\hline 4 & Forum for Modern Language Studies & (Gould, 2018) & 1 \\
\hline 5 & $\begin{array}{l}\text { Proceedings of the } 2018 \text { Conference of the } \\
\text { North American Chapter of the } \\
\text { Association for Computational Linguistics: } \\
\text { Human Language Technologies }\end{array}$ & (Ghazvininejad et al., 2018) & 1 \\
\hline 6 & $\begin{array}{l}\text { Indonesian Journal of English Language } \\
\text { Teaching and Applied Linguistics }\end{array}$ & (Prafitasari et al., 2019) & 1 \\
\hline 7 & International Journal of Humanity Studies & (Sukmajati \& Angelina, 2019) & 1 \\
\hline 8 & $\begin{array}{l}\text { Journal of Humanities and Social Sciences } \\
\text { Studies (JHSSS) }\end{array}$ & (Mayestika \& Tanjung, 2019) & 1 \\
\hline 9 & Babel Journal & (Liu \& Tang, 2020) & 1 \\
\hline 10 & Perspectives & (Queiroz et al., 2021) & 1 \\
\hline
\end{tabular}

The Result of Quality Assesment

The following is the result of quality assessment written in the form of a table:

Table 2 The Result Quality Assesment

\begin{tabular}{|c|c|c|c|c|c|c|c|}
\hline $\mathrm{Nr}$ & Writer & Heading & Year & QA1 & QA2 & QA3 & Result \\
\hline 1 & $\begin{array}{l}\text { Mohammad } \\
\text { Ali } \\
\text { Kharmandar, } \\
\text { Amin } \\
\text { Karimnia }\end{array}$ & $\begin{array}{l}\text { The Fundamentals of } \\
\text { Constructing a Hermeneutical } \\
\text { Model for Poetry Translation }\end{array}$ & (2013) & $\mathrm{Ya}$ & $\mathrm{Ya}$ & $\mathrm{Ya}$ & Accepted \\
\hline
\end{tabular}




\begin{tabular}{|c|c|c|c|c|c|c|c|}
\hline 2 & $\begin{array}{l}\text { Liliana B. } \\
\text { Prokopievaa, } \\
\text { Liliya T. } \\
\text { Leushinab }\end{array}$ & $\begin{array}{l}\text { Antiquity in Russian } \\
\text { Literature in the XVIII } \\
\text { Century (Anacreon's poetry } \\
\text { translated by M. N. } \\
\text { Muraviev) }\end{array}$ & (2014) & $\mathrm{Ya}$ & $\mathrm{Ya}$ & Ya & Accepted \\
\hline 3 & Louis Ndong & $\begin{array}{l}\text { German Poetry in African } \\
\text { Languages: The Translation } \\
\text { of Selected German Poems } \\
\text { From an Intercultural } \\
\text { Perspective }\end{array}$ & (2017) & $\mathrm{Ya}$ & $\mathrm{Ya}$ & Ya & Accepted \\
\hline 4 & $\begin{array}{l}\text { Rebecca } \\
\text { Ruth Gould }\end{array}$ & $\begin{array}{l}\text { Hard Translation: } \\
\text { Persianpoetry And Post- } \\
\text { Nationalliterary Form }\end{array}$ & (2018) & $\mathrm{Ya}$ & $\mathrm{Ya}$ & Tidak & Accepted \\
\hline 5 & $\begin{array}{l}\text { Marjan } \\
\text { Ghazvinineja } \\
\text { d, Yejin } \\
\text { Choi, Kevin } \\
\text { Knight }\end{array}$ & Neural Poetry Translation & $(2018)$ & $\mathrm{Ya}$ & $\mathrm{Ya}$ & Ya & Accepted \\
\hline 6 & $\begin{array}{l}\text { Aldita } \\
\text { Prafitasari, } \\
\text { MR } \\
\text { Nababan, } \\
\text { Riyadi } \\
\text { Santosa } \\
\end{array}$ & $\begin{array}{l}\text { An Analysis of Translation } \\
\text { Technique and Translation } \\
\text { Quality in Poem Book } \\
\text { Entitled Love \& } \\
\text { Misadventure }\end{array}$ & (2019) & $\mathrm{Ya}$ & $\mathrm{Ya}$ & Ya & Accepted \\
\hline 7 & $\begin{array}{l}\text { Bintang } \\
\text { Sukmajati, } \\
\text { Patricia } \\
\text { Angelina }\end{array}$ & $\begin{array}{l}\text { Poetry Translation } \\
\text { Acceptability On The Trials } \\
\text { Of Apollo: The Hidden } \\
\text { Oracle Novel }\end{array}$ & (2019) & $\mathrm{Ya}$ & $\mathrm{Ya}$ & Ya & Accepted \\
\hline 8 & $\begin{array}{l}\text { Vidha } \\
\text { Verdian } \\
\text { Mayestika, } \\
\text { Sufriati } \\
\text { Tanjung }\end{array}$ & $\begin{array}{l}\text { The Translation of Poetry } \\
\text { Ganymed by Johany } \\
\text { Wolfgang Von Goethe: } \\
\text { Heuristic Analysis and } \\
\text { Objective Approach }\end{array}$ & (2019) & $\mathrm{Ya}$ & $\mathrm{Ya}$ & Ya & Accepted \\
\hline 9 & $\begin{array}{l}\text { Liu Yongzhi } \\
\& \text { Tang } \\
\text { Chunlan }\end{array}$ & $\begin{array}{l}\text { Translation of visual poetic } \\
\text { spatiality }\end{array}$ & (2020) & Ya & $\mathrm{Ya}$ & Tidak & Accepted \\
\hline 10 & $\begin{array}{l}\text { João } \\
\text { Queiroz, } \\
\text { Marta } \\
\text { Castello- } \\
\text { Branco, Ana } \\
\text { Luiza } \\
\text { Fernandes, \& } \\
\text { Pedro Atã } \\
\end{array}$ & $\begin{array}{l}\text { Intersemiotic translation as a } \\
\text { cognitive artifact - from } \\
\text { Webern's serialism to } \\
\text { concrete poetry }\end{array}$ & (2021) & Ya & $\mathrm{Ya}$ & Ya & Accepted \\
\hline
\end{tabular}

Data Analysis

In this phase the data is analyzed and the results will answer the research question (RQ) that has been determined before and overall there are 10 journals obtained through the search process. 
Results from RQ1: Types of Translation Techniques

After the data is selected based on inclusion and exclusion criteria using keywords (keywords) "poetry or poem translation" there are 10 journal articles that are given quality assessment (Quality Assessment). From the results of Quality Assessment (QA) there are 10 relevant journal articles that are then grouped based on techniques, strategies, approaches and methods used to answer research questions. This result answers RQ1, which is displayed in table 3 as follows:

Table 3. Types of Poetry Translation Techniques

\begin{tabular}{|c|l|c|c|}
\hline Nr & \multicolumn{1}{|c|}{ Type of technique } & Research article & Sum \\
\hline 1 & Peminjaman dan Parafrasa & No 3. dan No 6 & 2 \\
\hline 2 & Hard Translation & No 4. & 1 \\
\hline 3 & $\begin{array}{l}\text { Biased Decoding with Unconstrained } \\
\text { Translation and Biased Decoding with } \\
\text { All Potential Translation }\end{array}$ & No 5. & 1 \\
\hline 4 & $\begin{array}{l}\text { Kesepadanan, modulasi, amplifikasi, } \\
\text { variasi, kompensasi, kreasi diskursif, } \\
\text { transposisi, partikularisasi, } \\
\text { peminjaman murni, literal, dan } \\
\text { reduksi. }\end{array}$ & No 6. & 1 \\
\hline 5 & Terjemahan secara Harfiah / Literal & No 7. & 1 \\
\hline 6 & Membaca gaya Heuristik & No 8. & 1 \\
\hline 7 & Tanda-tanda Linguistik & No 9. & 1 \\
\hline 8 & Terjemahan Intersemiotik & No 10. & 1 \\
\hline 9 & Hermeneutis & No 1. & 1 \\
\hline 10 & Terjemahan bebas dan adaptasi & No 2. & 1 \\
\hline
\end{tabular}

Using the method of systematic literature review, the author obtains the fact and data that every age, every nation, and every culture in solving the problem of poetry translation, solved in its own way, meaning that there are various techniques and strategies used by each translator in pouring the meaning of poetry from the source language to the target language.. In the reviewed study, it was proposed that translation theory incorporate certain recognizable elements into a systematic framework for analyzing poetry translations. Basically, the two suggested categories are: the language-culture complexity level, and the hermeneutic level of complexity (Kharmandar \& Karimnia, 2013). Some use free translation in accordance with the classical translation tradition of the time when the main criterion of translation was to convey the general idea of a text of a poem so that adaptation could occur (Prokopieva \&Leushina, 2014). Translation theory should develop a flexible approach to poetry translation.

Another technique used is to explore translation methods and strategies such as borrowing, paraphrasing, and further analyzing some of the differences seen in the translation of some poems that belong to cultural aspects. Such analytical measures allow contextual investigation of the central issue of "cultural translation ability" and examples on the translation of European poetry into African languages and German poetry into Wolof-African (Ndong, 2017). Hard translation as a method that 
combines translation in the form of interpretation, while maintaining traces of the source language in the target language (Gould, 2018). In addition, there are two new methods produced in research that has been done before is to improve the quality of poetry translation, namely the Method Biased Decoding with Unconstrained Translation and Biased Decoding with All Potential Translation (Ghazvininejad et al., 2018).

Another study explained that the translation technique most dominantly used by translators is the equidity (Prafitasari et al., 2019). There are 11 techniques applied in translating selected poems, namely; established equivalents, modulation, amplification, variation, compensation, discursive creation, transposition, particularization, pure lending, literal, and reduction. Referring to the theory of translation acceptance, Larson (1984), argued that translation should also use the natural form of the target language, convey the same meaning to the target language, and maintain the dynamics of the source language, and there are parts of poetry that are translated literally.

Thus, there are four points that can be concluded from the study. First, to determine the acceptance of a poem, a method of interpretation must be used to find the core of the poem. Second, the translation of a poem is influenced by the content of the chapter or its context. Third, syllables do not affect acceptability because Indonesian tend to have more syllables than English. In other words, keeping meaning is more important than following the rules of syllables. Fourth, to obtain an acceptable translation of poetry, the translator does not always have to follow the principles but still pay attention to them.

Furthermore, heuristic reading is used to know literary meaning and is done through an objective approach to knowing the intrinsic component in the translation of poetry by Johann Wolfgang von Goethe (Mayestika \& Tanjung, 2019). Please note that written texts such as poetry have their visual poetic space. The scenarioal properties of such linguistic signs such as letters, character parts, words and so on (Liu \& Tang, 2020). The analysis was used against iconic English-Mandarin and Mandarin-English translations of the poem's iconic letters, lineages, distances, and sequences to reveal that some poetry translations had successfully reproduced the visual spatiality of the source text in the target text.

As a metasemiotic tool, intersemiotic translation creates a semiotic metalevel process, a sign action that stands for sign action (Queiroz et al., 2021). In a systematically reviewed literature study the newness in this study was to explore these ideas by utilizing one example of an intersemiotic translation into verbal poetry from Webern's musical serialism to Poetamenos by Augusto de Campos. Poetamenos is an intersemiotic translation of Webern's music. Some of the translated properties of Webernia serialism are the abstraction of musical lines, the fragmentation of melodies between low, medium and high registers. The study also paid attention to proportional duration and exchange of elements, in addition to temporal symmetry. In 
accordance with the development of technology, a wide variety of translation techniques have been found that are new and used in translating poetry literary works.

\section{Conclusion}

Based on the results of research reviews that have been conducted, it can be concluded that the results of Systematic Literature Review or SLR, there are twentyone (21) kinds of techniques used by translators in translating poetry literary texts, namely: lending, paraphrasing, hard translation methods, biased decoding methods with unconstrained translation and biased decoding with all potential translation, established equivalents, modulation, amplification, variation, compensation, discursive creation, transposition, particularization, literal, reduction, reading heuristic styles, paying attention to linguistic signs, intersemiotic translation techniques, hermeneutics, free translation and adaptation. These techniques can be used according to the needs and purpose of the translator in expressing the meaning of the poem translated from the source language into the target language, so that the uniqueness of the literary text is maintained.

\section{References}

Ghazvininejad, M., Choi, Y., \& Knight, K. (2018). Neural poetry translation. Proceedings of the 2018 Conference of the North American Chapter of the Association for Computational Linguistics: Human Language Technologies, Volume 2 (Short Papers), 67-71.

Gould, R. R. (2018). Hard translation: Persian poetry and post-national literary form. Forum for Modern Language Studies, 54(2), 191-206. https://doi.org/https://doi.org/10.1093/fmls/cqx039

Hatim, B., \& Munday, J. (2013). Translation An Advanced Resource Book. In Journal of Chemical Information and Modeling (Vol. 53, Issue 9).

Kartika, Y. (2017). The translation techniques of emily dickinson's poem hope of two Indonesian translations. UIN Syarif Hidayatullah Jakarta: Fakultas Adab dan Humaniora, 2017.

Kharmandar, M. A., \& Karimnia, A. (2013). The Fundamentals of Constructing a Hermeneutical Model for Poetry Translation. Procedia - Social and Behavioral Sciences, 70, 580-591. https://doi.org/https://doi.org/10.1016/ j.sbspro.2013.01.096

Kitchenham, B., Pearl Brereton, O., Budgen, D., Turner, M., Bailey, J., \& Linkman, S. (2009). Systematic literature reviews in software engineering - A systematic literature review. Information and Software Technology, 51(1), 7-15. https://doi.org/10.1016/j.infsof.2008.09.009

Kudriyah, S. (2020). Penerjemahan Puisi "Aus Dem Tagebuch Der Ehe." Bahas, 31(3), 121-127. https://doi.org/https://doi.org/10.24114/bhs.v31i3.20198

Liu, Y., \& Tang, C. (2020). Translation of visual poetic spatiality. Babel, 66(4-5), 796-810. https://doi.org/https://doi.org/10.1075/babel.00185.liu 
Mayestika, V. V., \& Tanjung, S. (2019). The Translation of Poetry Ganymed by Johany Wolfgang Von Goethe: Heuristic Analysis and Objective Approach. Journal of Humanities and Social Sciences Studies, 1(3), 6472.

Ndong, L. (2017). German Poetry in African Languages: The Translation of Selected German Poems From an Intercultural Perspective. Journal of Literature and Art Studies, 7(3), 255-263. https://doi.org/10.17265/21595836/2017.03.002

Newmark, P. (1988). A textbook of translation (Vol. 66). Prentice hall New York.

Nurhidayah, V. A. (2018). Penerjemahan Puisi. Diglossia: Jurnal Kajian Ilmiah Kebahasaan Dan Kesusastraan, 9(2), 123-138. https://doi.org/http://dx. doi.org/10.26594/diglossia.v9i2.1142

Prafitasari, A., Nababan, M. R., \& Santosa, R. (2019). An Analysis of Translation Technique and Translation Quality in Poem Book Entitled Love \& Misadventure. IJELTAL (Indonesian Journal of English Language Teaching and Applied Linguistics), 3(2), 313-333. https://doi. org/http://dx.doi.org/10.21093/ijeltal.v3i2.215

Prihantono, K. D. (2014). Analisis Penerjemahan Puisi "Grodek" Karya Georg Trakl: Sebuah Kajian Ekstratekstual. Alayasastra.

Prokopieva, L. B., \& Leushina, L. T. (2014). Antiquity in Russian Literature in the XVIII Century (Anacreon's Poetry Translated by M. N. Muraviev). Procedia - Social and Behavioral Sciences, 154, 504-508. https://doi.org/https://doi.org/10.1016/j.sbspro.2014.10.202

Queiroz, J., Castello-Branco, M., Fernandes, A. L., \& Atã, P. (2021). Intersemiotic translation as a cognitive artifact - from Webern's serialism to concrete poetry. Perspectives, 1-25. https://doi.org/10.1080/0907676X. 2021.1990368

Salleh, N. M., \& Ahmad, M. (2015). Tinjauan Literatur Penterjemahan Novel Melayu ke Bahasa Arab. Islamiyyat, 37(2), 147-152. https://doi.org/http: //dx.doi.org/10.17576/islamiyyat-2015-3702-06

Sukmajati, B., \& Angelina, P. (2019). Poetry Translation Acceptability On The Trials Of Apollo: The Hidden Oracle NoveL. International Journal of Humanity Studies (IJHS), 3(1), 76-83. https://doi.org/https://doi.org/ 10.24071/ijhs.v3i1.2016

Zemova, M. I., \& Bozhko, E. M. (2019). Translation of poetry. Languages in Professional Communication, 263-267. 